УДК [373.5.011.3-051:908]:001.895

DOI: https://doi.org/10.35619/iiu.v0i9.131

Пустовіт Григорій

доктор педагогічних наук, професор,

професор кафедри природничо-математичної освіти

Рівненського обласного інституту післядипломної педагогічної освіти,

м. Рівне, Україна

ORCID: 0000-0001-7754-0249,

e-mail: h.pustovit@gmail.com

\begin{abstract}
Зиль Іван
доцент кафедри екології, географії та туризму

Рівненського державного гуманітарного університету,

м. Рівне, Україна

ORCID: 0000-0002-1380-0432,

e-mail:ivan_zil@ukr.net
\end{abstract}

\title{
КРАЄЗНАВЧА КОМПЕТЕНТНІСТЬ УЧИТЕЛІВ ГЕОГРАФІЇ В ІННОВАЦІЙНОМУ РОЗВИТКУ ШКІЛЬНОЇ ОСВІТИ
}

\begin{abstract}
Анотація. У статті виокремлено й схарактеризовано сутнісні ознаки формування краєзнавчої компетентності вчителів географії в інноваційному розвитку шкільної освіти, особливості i, головне, можливості формування досліджуваного феномена та його вплив на розвиток і саморозвиток вчителя. Актуалізовано, що саме краєзнавча компетентність вчителя географії передбачає володіння глибокими знаннями з конкретної галузі професійної діяльності (у нашому трактуванні з організації і здійснення суто краєзнавчої роботи дітей та учнівської молоді), сформовану стійку мотиваційно-емоційну установку на досягнення високого результату власної професійної діяльності, на розвиток здібностей, особистісних якостей, творчого ставлення до навчання зростаючої особистості. Тому краєзнавчу компетентність учителів географії визначено й обгрунтовано як багатофакторну особистісну якість, у структурі якої усталеними $\epsilon$ такі компетенції: мотиваційна; емоційно-ціннісна; активно-пізнавальна; предметнопрофесійна; саморозвитку; дослідницька. Розкрито й схарактеризовано ознаки самостійності вчителя географії у розвитку своїх професійних знань, умінь і навичок $з$ організації і здійснення краєзнавчої роботи дітей та учнівської молоді у школі. Враховуючи сутність і специфіку організації і здійснення вчителем географії навчально-пізнавальної, пошуково-експериментальної і дослідницької діяльності краєзнавчого спрямування та конкретної суспільно корисної, масової чи природоохоронної роботи учнів, визначено рівні її здійснення.

Ключові слова: краєзнавча компетентність, компетенції, вчитель географії, інноваційний розвиток освіти, краєзнавча робота, учень, освітньо-виховний процес, саморозвиток.

Постановка проблеми. Пріоритетними напрямами розвитку сучасної української школи $є$ особистісна орієнтація на здобуття якісної освіти, компетентнісний підхід, розвиток системи безперервної освіти й освіти впродовж життя та створення умов для ефективного формування умінь i навичок самостійного пізнання найближчого довкілля, самоосвіти й
\end{abstract}


самореалізації зростаючої особистості. Відповідно до нормативно-правових документів про сучасну освіту серед основних якостей особистості $\epsilon$ сформована здатність самостійно, швидко, якісно й безперервно вдосконалювати власні життєво важливі компетентності (Кремень та Ільїн, 2012; Верховна рада України, 2001; Пустовіт, 2014, с. 152-163; Пустовіт, 2011, c. 17-19).

Сутність поняття компетентність трактується як «...динамічна комбінація сформованих знань, умінь i практичних навичок, способів мислення, професійних, світоглядних i громадянських якостей, морально-етичних цінностей майбутніх вчителів, визначають їхню здатність успішно здійснювати професійну та подальшу навчальну діяльність в закладах середньої освіти» (Верховна рада України, 2014, с. 2).

У контексті зазначеного можемо зробити висновок, що компетентнісний підхід сьогодні розглядається як один з провідних напрямів професійного зростання вчителя, його особистісного розвитку, й головне, саморозвитку, на основі удосконалення ним здобутих раніше освітніх і соціально важливих знань, умінь, практичних навичок (компетенцій); вироблення умінь і навичок самостійно планувати ефективність власних освітніх результатів у процесі постійної самооцінки; застосування різноманітних як традиційних, так i інноваційних форм організації самостійної, осмисленої професійної діяльності на основі власної мотивації та відповідальності за ііі результат.

Запровадження компетентнісного підходу до підготовки учителів географії зумовлене потребою розвитку системного бачення змісту географічної освіти, прогнозування результативної складової навчання, що вимагає адекватних змін у системі підготовки вчителів.

Краєзнавчий матеріал відіграє важливу роль, пов'язуючи життя і побут будь-якого населеного пункту країни 3 поняттям Батьківщини. Краєзнавчий принцип вивчення предмета сприяє усвідомленому засвоєнню найскладніших питань, і продуктивним такий підхід буде лише тоді, коли вивчення природи, господарства і економіки України буде розглядатися одночасно з місцевими явищами. Знання свого краю необхідні для безпосередньої участі в його перетворенні, формуванні поваги до національних здобутків народу, бережливого ставлення до рідної природи, планети в цілому.

3 огляду на це у підготовці вчителя географії постає нагальне завдання формування краєзнавчої компетентності в інноваційному розвитку шкільної освіти.

Аналіз останніх досліджень 3 проблеми. Важливою складовою досліджуваної проблеми $\epsilon$ розгляд вчителя як суб'єкта активної життедіяльності в соціокультурному $\mathrm{i}$ соціоприродному середовищі й психолого-педагогічних механізмів активності і самоактивності, що набули характеристики у наукових працях К. О. Абульханової-Славської, Б. Г. Ананьєва， Г. О. Балла， І.Д.Беха， М. Й. Боришевського, Л.І.Божович, О. В. Киричука, Я. Л. Коломенського, С. Д. Максименка Р. В. Павелківа та ін.

Дослідження процесів становлення і розвитку шкільного краєзнавства, залучення до цієї роботи учнів різного віку, форм і методик ії організації охарактеризовано у наукових дослідженнях та працях Л. Л. Бабенко, В.В.Бенедюк, О. М. Костюкової, В. В. Приймачук, Н. Ю. Рудницької, $\begin{array}{llll}\text { Є. 3. Рут, } & \text { М. В. Соловея, } & \text { С. В. Совгіри, } & \text { В. П. Струманського, }\end{array}$ М. Г. Стельмаховича, П. Т. Тронька та ін. (Вішнікіна, 2017) 
Різні аспекти компетентнісного навчання географії були предметом аналізу Л. П. Вішнікіної, Т. О. Дібрової, О. М. Топузова, Г. Ш. Уварової, Б. П. Яценка та ін. Практичні аспекти формування краєзнавчої компетентності учнів висвітлювали Н. Г. Побидайло, Н. М. Фідря, Н. М. Чернявська та ін. Утім існує потреба у працях теоретичного та прикладного характеру, у яких аналізувався $б$ процес формування краєзнавчої компетентності вчителів географії (Побидайло, 2017).

Мета статті полягає у виокремленні й характеристиці сутнісних ознак формування краєзнавчої компетентності вчителів географії в інноваційному розвитку шкільної освіти.

Виклад основного матеріалу дослідження. Сьогодні усталеним $\epsilon$ визнання п’яти ключових компетентностей, які мають бути сформовані у кожного з вчителів української школи, відповідно, й в учителів географії:

1) політичні й соціальні компетентності, що передбачають здатність усвідомлювати свою відповідальність, брати участь у спільному ухваленні рішень, сприяти розв'язанню конфліктів ненасильницьким шляхом, долучатися до функціонування й удосконалення діяльності демократичних інститутів;

2) компетентності, пов'язані з життям у багатокультурному суспільстві, що екстраполюються у проявах поважного ставлення кожного з членів громади чи суспільства один до одного, розуміння і сприйняття ідей і поглядів інших національностей, культур, мов і релігій. Саме ці компетентності визначають соціальну зрілість вчителя;

3) компетентності, що забезпечують володіння особистістю усним i письмовим мовленням;

4) компетентності, що забезпечують ефективне використання нових інформаційних технологій, ефективним їх застосуванням у професійній діяльності;

5) компетентності, що детермінують мотиви i потреби вчителя самостійно вчитися протягом життя (Локшина, 2007, с. 16-21).

Актуальність формування краєзнавчої компетентності вчителя географії $€$ відображенням сутності сучасних концептуальних, теоретичних, прикладних теорій і концепцій та ряду нормативних документів про розвиток сучасної української школи і зокрема впровадження НУШ протягом найближчого десятиліття. У зазначених документах наголошується, що застосування краєзнавчого принципу у розгляді змісту освіти як одного 3 провідних у побудові системи наукових знань учнів та формування умінь i навичок їх ефективного застосування у власній навчально-пізнавальній i соціально значущій діяльності є пріоритетним напрямом загальної середньої освіти.

Саме краєзнавча компетентність вчителя географії передбачає володіння глибокими знаннями 3 конкретної галузі професійної діяльності (у нашому трактуванні 3 організації i здійснення суто краєзнавчої та туристськокраєзнавчої роботи дітей та учнівської молоді), сформовану стійку мотиваційно-емоційну установку на досягнення високого результату власної професійної діяльності, на розвиток здібностей, особистісних якостей, творчого ставлення до навчання зростаючої особистості.

Отже, краєзнавчу компетентність учителів географії визначаємо як багатофакторну особистісну якість, що:

- по-перше; є результатом набуття певних компетенцій та проявляється у готовності до ефективної професійної діяльності вчителя географії, основою 
якої є набуті системні знання, уміння і практичні навички їх застосування як на уроках географії, так і у процесі організації краєзнавчої роботи школярів за межами школи;

- по-друге - застосуванням у професійній діяльності індивідуального практичного досвіду вивчення особливостей рідного краю, де ключову роль відіграють пізнавальні дії дослідницького характеру (на уроках, екскурсіях, під час туристських походів, подорожей, експедицій тощо);

- по-третє - визнанням й усвідомленням цінності сформованих професійних якостей, (толерантний стиль суб'єкт-суб'єктної взаємодії в учнівсько-педагогічному колективі, спілкування з батьками, відповідальність за якість своєї професійної діяльності, потреба у творчому іiі здійсненні та постійному підвищенні свого фахового рівня).

У структурі краєзнавчої компетентності учителів географії сьогодні усталеними $є$ такі компетенції: мотиваційна; емоційно-ціннісна; активнопізнавальна; предметно-професійна; саморозвитку; дослідницька.

Зокрема, мотиваційна компетенція передбачає сформованість мотивації вчителя до організації і здійснення краєзнавчої роботи дітей та учнівської молоді, усвідомленням ऑiі цінності для удосконалення змісту шкільної географічної освіти та розуміння іiі значущості для розширення наукового світогляду учнів, поглиблення їхніх знань про історію, природу, культуру i сьогодення рідного краю. Як зазначає І. Д. Бех, ознакою якості самостійної дії $\epsilon$ те, що учень розпочинає іï під впливом внутрішніх спонукань, керується стимулами, які випливають із середини (Бех, 2006).

Особливо важливим $\epsilon$ формування в учнів освітніх мотивів, що $\epsilon$ детермінантами організації $\mathrm{i}$ здійснення їхніх самостійних краєзнавчих досліджень. Тобто сформована мотиваційна компетенція вчителя географії $\epsilon$ його внутрішнім спонуканням до цілеспрямованої якісної професійної діяльності і водночас сприяє виробленню освітніх мотивацій у школярів, які, у свою чергу, спонукають їх до активної участі в краєзнавчій роботі. Тож, формування таких мотивів-стимулів сприяє підвищенню професійнопедагогічної діяльності учителя. А в умовах реформування сучасної освіти формування мотиваційної компетенції вчителя географії $\epsilon$ безпосередньою екстраполяцією одного з провідних принципів іiї функціонування: навчити учня самостійно здобувати знання, формувати уміння і навички їх ефективного застосування у власній життєдіяльності, а вчителя самостійно підвищувати свій професійний рівень. У такому контексті центральне місце у професійній діяльності вчителя посідає мотивація як форма вияву потреби у саморозвитку й самовдосконаленні (Бондар, 2008).

Отже, емоційно-ціннісна компетенція є суб'єктивною формою прояву емоційних характеристик власної професійної діяльності учителя, що виникають у процесі ії здійснення, тим самим детермінують мотиви і спонуки до підвищення ефективності цієї діяльності. Тому, формування і розвиток емоційно-ціннісної компетенції вчителя базується на функціональній єдності емоційних і мотиваційних процесів (Бех, 2003).

У цьому контексті можемо стверджувати, що у процесах організації і здійснення учителем географії краєзнавчої роботи емоції відіграють важливу роль, оскільки саме вони концентрують увагу школяра та спрямовують його до дії. Позитивний емоційний стан під час організації і здійснення краєзнавчої роботи як учителя, так і учнів забезпечує отримання ними задоволення від 
такої роботи. 3 огляду на це, можемо констатувати, що у краєзнавчо орієнтованій діяльності емоція $є$ чинником, завдяки якому оцінюється дійсність із позиції того, наскільки вчителеві географії вдалося в ній реалізувати себе. Отже, саме емоції трансформуються у систему життєвих цінностей, які в подальшому стимулюватимуть всю професійної діяльність вчителя.

Створення емоційної привабливості краєзнавчо орієнтованої роботи сприяє формуванню у свідомості учнів новизни емоцій i почуттів, i, як результат, розвитку інтересу до вивчення вже відомих їм навколишніх об'єктів і явищ тільки у іншій, раніше невідомій для них площині. За таких умов інтерес $\epsilon$ не лише поштовхом до формування позитивного забарвлення здійснюваної вчителем професійної діяльності, але й сприяє формуванню сукупності мотивів до навчання та здійснення самостійних краєзнавчих досліджень. Поряд 3 емоціями важливим $\epsilon$ формування й, головне, удосконалення, розуміння учителем цінності власної професійної діяльності. Таким чином, саме ціннісні орієнтації становлять основу світогляду вчителягеографа, забезпечують оволодіння прийомами самоаналізу і самоконтролю, сприяють особистісному самовдосконаленню, розвиткові професіоналізму й творчості (Асмолов, 2001).

Визнаючи спектр цінностей професійної діяльності, акцентуємо увагу на тому, що провідними цінностями для вчителя-географа $\epsilon$ : освіченість, упевненість у собі, справедливість, самостійність, терпимість до думок інших, особистісний розвиток (самовдосконалення), творчість, любов до дітей, цікава робота, визнання колег, матеріальне забезпечення життя, професійний досвід. До особистісних цінностей варто додати усвідомлення важливості краєзнавчої роботи з учнями, розвиток ціннісних орієнтацій як вищої форми цінностей, сформованість моральних і духовних потреб, національної свідомості, патріотизму.

Активно-пізнавальна компетенція. Досягнення якісних результатів у формуванні i розвитку власної краєзнавчої компетентності необхідним $\epsilon$ опанування раціональними прийомами розумової діяльності - порівнювати об'єкти спостережень і явища; аналізувати їх та синтезувати, виділяти головне, робити правильні висновки й узагальнення, свідомо аналізувати предмети, об'єкти і явища у взаємозв'язку; доводити істинність своїх думок. Заразом, активно-пізнавальна компетенція передбачає набуття учителем нового досвіду організації і здійснення краєзнавчої роботи у школі, відповідно, набуття нових наукових знань, умінь, навичок їх застосування на практиці, результатом чого стає особистісний розвиток і самовдосконалення. 3 огляду на це О. Леонтьєв стверджував, що «...в опануванні будь-якими знаннями узагалі важливе те, яке місце в житті людини посідає пізнання, чи $є$ воно для неї частиною життя або тільки зовнішньою, нав'язаною ззовні умовою» (Леонтьев, 1972; Леонтьев, 1977, c. 104).

Через площину аналізу ефективності використання компетенцій можемо дійти висновку, що пізнання учнями навколишньої дійсності, особливостей рідного краю як активного, творчого процесу відображення у їхній свідомості зв'язків і закономірностей об'єктивного світу, відбувається ефективно лише тоді, коли цей процес має творче спрямування. Тобто, опрацювання учнем здобутої краєзнавчо спрямованої інформації має здійснюватися через ії аналіз, синтез, систематизацію, усвідомлення, запам'ятовування, застосування у 
практичній роботі, а не як відображення процесу елементарного заучування. У той же час досягти таких результатів можливо лише тоді, коли вчитель у своїй професійній діяльності розширює і поглиблює свій власний пізнавальний інтерес, що виявляється в потребі здобуття нових знань. I тут можна запропонувати кілька напрямів підвищення якості власної професійної діяльності, а саме: розвивати особисту пізнавальну активність, поглиблювати самостійний пошук i опрацювання інформації, що сприяє виробленню професійного досвіду.

Отже, активно-пізнавальну компетенцію вчителя як складову його краєзнавчої компетентності слід розглядати як здатність і прагнення до оволодіння новими знаннями й дослідницькими краєзнавчо орієнтованими уміннями та навичками її здійснення, як властивість особистості вчителя, що інтегрує його важливі якісні професійні характеристики.

Предметно-професійна компетенція вчителя як складова його краєзнавчої компетентності відображає наявність у нього системно сформованих і логічно побудованих теоретичних знань про зміст, основні форми і методи організації і здійснення краєзнавчої роботи у школі. Характеризує вчителя географії як краєзнавця-дослідника, його готовність і здатність до аналізу власної професійної діяльності, розвиток особистісних якостей (цілеспрямованість, творчість, упевненість, активність, самостійність, відповідальність, креативність, гнучкість, критичність, системність, мобільність, оперативність мислення в нестандартних ситуаціях тощо). Крім глибоких знань із краєзнавства, предметно-професійна компетенція передбачає самостійність вчителя в осмисленні пізнавальних краєзнавчих завдань, оригінальність у способах їх розв’язання, створення в краєзнавчій роботі ситуацій, що сприяють творчому розвиту учнів.

За нашим переконанням, складовою цієї компетенції вчителя географії $\epsilon$ загальні та спеціальні знання, необхідні для організації і ефективного здійснення майбутньої краєзнавчої роботи учнів, що охоплюють такі основні чинники: теоретичні знання цілей, принципів, змісту, форм, методів і засобів краєзнавчої роботи та закономірностей формування й розвитку особистості учня; знання загальних принципів вивчення педагогічних явищ; спеціальні знання з історії, форм та методик вивчення рідного краю; технологічні знання про форми і методи проведення краєзнавчої роботи учнів, організації їхньої творчої дослідницької діяльності.

Предметно-професійна компетенція як провідна 3 переліку інших компетенцій у формуванні краєзнавчої компетентності передбачає опанування вчителем географії системно сформованих професійно важливих знань, умінь, навичок у галузі краєзнавства, методів розв'язання педагогічних завдань 3 організації краєзнавчої роботи учнів, а також уможливлює здатність учителя до безперервного самостійного професійного розвитку і саморозвитку.

Окреме важливе місце у формуванні краєзнавчої компетентності вчителя географії посідає компетенція саморозвитку, що за своєю сутністю відображає його готовність використовувати систему здобутих знань, умінь, навичок у процесі організації і здійснення краєзнавчої роботи для власного саморозвитку, здатність до самоорганізації в пізнавально-дослідницькій діяльності (ставити мету, уміння планувати краєзнавчу роботу, визначати об'єкт і предмет дослідження, узагальнювати знайдену інформацію краєзнавчого змісту, 
користуватися різноманітними методами польових досліджень, контролювати й оцінювати результати краєзнавчої роботи учнів).

Ця сформована компетенція маркує готовність вчителя географії до вольових зусиль і їх реалізацію в процесі організації і здійснення краєзнавчої роботи учнів. А це, у свою чергу, дає змогу визначати власний рівень професійних знань вчителем та окреслювати основні напрями їх удосконалення. Вольові зусилля залежать від характеру того, хто ставить мету навчально-пізнавальної діяльності (вчитель-учень), від співвідношення мотивів та цілей, які можуть збігатися чи не збігатися. Тому вчитель має визначально усвідомлювати результат краєзнавчої роботи, до якої він залучає учнів.

Важливо закцентувати увагу на тому, що максимальні вольові зусилля в пізнанні навколишньої дійсності учнями пов'язані, насамперед, з формуванням у них умінь і навичок самостійно формулювати мету власної пізнавальної діяльності, що детермінується потребами і мотивами та інтересом суб'єкта, наполегливістю у досягненні визначеної ним самим чи у взаємодії з вчителем мети, виробленням навичок самостійного здійснення краєзнавчої роботи чи окремих краєзнавчих завдань. Отже, усвідомлення вчителем потреби активізації пізнавальних дій учнів як у їхній самостійній, так і колективній краєзнавчій роботі, передбачає створення ним «ситуації успіху», що сприяє вихованню віри у свої сили, формує у них навички самооцінювання здобутих результатів та їх ефективності у досягненні поставленої вчителем мети і розв'язанні навчальних завдань (Бех, 2008).

За нашим переконанням, ознаками самостійності вчителя географії у розвитку своїх професійних знань, умінь і навичок організації і здійснення краєзнавчої роботи дітей та учнівської молоді у школі $є$ :

- спрямованість на засвоєння нових знань, умінь, навичок і засобів здійснення такої роботи (за умови сформованості умінь і навичок самостійно працювати 3 науковою, науково-популярною, навчальною, спеціальною літературою, довідниками, першоджерелами краєзнавчого змісту);

- наявність сформованого особистісного інтересу до процесу самостійного і творчого розв'язання учнями пізнавальних краєзнавчих завдань (за умови сформованості умінь і навичок визначати мету й окреслювати завдання діяльності учнів, визначати етапи роботи і їх зміст, розподіляти навчальний час на їх реалізацію, обирати напрями й ефективні засоби досягнення мети, здійснювати контроль за досягнутими результатами учнів);

- володіння уміннями самостійно мислити, творчо вирішувати завдання, аналізувати, систематизувати, виділяти головне, узагальнювати тощо (за умови сформованості умінь і навичок креативного мислення, пошуку альтернативних чи інноваційних підходів, форм і методів організації краєзнавчої роботи учнів).

Прикладним аспектом формування краєзнавчої компетентності вчителів географії $\epsilon$ наявність сформованості провідної компетенції, а саме дослідницької компетенції. Важливість ії сформованості полягає у створенні таких умов, при яких вчитель особисто може здійснити не лише організацію і проведення краєзнавчої роботи учнями, а головне, переконатись на практиці в ефективності професійної діяльності, виявити недоліки своєї роботи та визначити можливі напрями їх усунення. За нашим переконанням, результатом сформованості дослідницької компетенції $\epsilon$ здобуті вчителем знання та практичні уміння й навички, що саме і забезпечують ефективне здійснення 
дослідницької краєзнавчої діяльності як його власної, так і організації дослідницької діяльності учнів, що можна об'єднати в кілька груп:

- уміння і навички цілепокладання та планування краєзнавчої роботи, сформованість яких забезпечує: ефективне й педагогічно доцільне визначення мети i конкретних навчально-виховних завдань для учнів; обгрунтування змісту етапів і засобів організації колективної чи індивідуальної дослідницької роботи краєзнавчого змісту; проектування кінцевого результату такої роботи; визначення й обгрунтування найбільш ефективних способів досягнення ефективних результатів;

- інформаційні уміння i навички, сформованість яких сприяє: ефективному визначенню змісту необхідної для організації краєзнавчої роботи учнів наукової, навчально-популярної, історичної чи довідникової інформації, iii пошуку, аналізу, систематизації та узагальненню; створенню умов для стимулювання інтересу учнів до краєзнавчої інформації та розвитку їхньої навчально-пізнавальної активності у пошуку, опрацюванню й засвоєнню такої інформації;

- організаційно-управлінські уміння i навички, вироблення яких забезпечує: умови для ефективної педагогічно орієнтованої організації життєдіяльності учнів як на уроці географії, так і під час позаурочної та позакласної роботи; координації власної професійної діяльності і навчальнопізнавальної діяльності учнів; співпрацю 3 колегами й учнями та їхніми батьками; формування відчуття причетності до спільної соціально-значущої діяльності, що забезпечується орієнтацією кожного учня на успіх власної роботи;

- результатом сформованості умінь і навичок аналізу й самоаналізу власної педагогічної діяльності $є$ : ефективна освітньо-виховна робота вчителя як на уроці, так і у процесі позаурочної i позакласної роботи учнів краєзнавчого спрямування; вивчення колективу класу (гуртка чи секції) та кожного учня, діагностування рівня їхньої навчальної успішності й вихованості; аналіз якості виконання учнями завдань краєзнавчого змісту, досвіду інших педагогів для використання ефективних форм, методів і засобів у власній практиці організації і здійснення краєзнавчої роботи (Пустовіт, 2016, с. 15-27).

Водночас, слід пам'ятати, що не менш важливими є уміння і навички учителів географії педагогічно доцільно використовувати заохочення та покарання у їх розумному поєднанні, що дає змогу створювати атмосферу комфортності як для педагога, так і для кожного з учнів у процесі здійснення краєзнавчих досліджень.

Висновки і перспективи подальших розвідок. Проведене дослідження дає підстави для такого висновку: формування краєзнавчої компетентності вчителя географії передбачає набуття важливого педагогічного досвіду з активізації навчально-пізнавальної діяльності учнів, що фіксується у формі його результатів - системних і логічно вибудуваних наукових знань зростаючої особистості у галузі краєзнавства, досвіду творчої діяльності, самостійному розв'язанні навчальних завдань краєзнавчого змісту з вирішення місцевих екологічних, природоохоронних чи суспільних проблем, що є важливими як для окремої зростаючої особистості, так і громади, членом якої вона $\epsilon$.

Зміст статті не вичерпує наукове розуміння формування досліджуваного феномена у вчителів географії. Перспективи подальших розвідок вбачаємо у 
пошуку ефективних інноваційних підходів підвищення фахового рівня вчителя географії, у розробленні інноваційних методик його самоосвіти і саморозвитку.

\section{СПИСОК ВИКОРИСТАНИХ ДЖЕРЕЛ:}

Кремень, В. та Ільїн, В. (2012). Синергетика в освіті: контекст людиночентризму : монографія. Київ: Педагогічна думка, 368 с.

Верховна рада України, (2001). Національна доктрина розвитку освіти в Україні у XXI столітті. Київ: Шкільний світ, 24 с.

Пустовіт, Г. (2014). Компетентнісний підхід у змістових конструктах освіти й виховання особистості в позашкільних навчальних закладах: теоретичні концепти. Науковий вісник Чернівецького університету. Збірник наукових праць Випуск 689. Педагогіка і психологія. Вип.718. С. 152-163.

Пустовіт, Г. (2011) Позашкільні навчальні заклади - погляд у майбутнє. Нова педагогічна думка: матеріали Всеукраїнської науково-практичної конференції ["Формування сочіальної компетентності вихованців позашкільних навчальних закладів”]. Рівне. № 3. С. 17-19.

Верховна рада України, (2014). Закон Украӥни «Про вищу освіту». Режим доступу : URL: http://zakon2.rada.gov.ua/laws/show/1556-18/page. [Дата звернення 3 березня 2019].

Вішнікіна, Л. (2017). Структура предметної географічної компетентності учнів (рекомендації для вчителів географіi). Українська професійна освіта : науковий журнал Полтава. Вип. 1. с. 103-112.

Побидайло, Н. (2017). Формування краєзнавчої компетентності на заняттях із фізичної географії україни. Професіоналізм педагога: теоретичні й методичні аспекти. № 6.6 Режим доступу: http://pptma.dn.ua/files/2017/6/18.\%20Pobidailo\%20159-168.pdf. [Дата звернення 4 березня 2019]

Локшина, О. (2007). Розвиток компетентнісного підходу в освіті Європейського Союзу. Шлях освіти. № 4. с 16-21.

Бех, I. (2006). Виховання особистості: Сходження до духовності: Наукове видання. Кн. - 3. Київ: Либідь, 2006. 272 с.

Бондар, В. (2008). Навчальна діяльність. Енциклопедія освіти. Київ: Хрінком Iнтер, $1040 \mathrm{c}$.

Бех, І. (2003). Виховання особистості : у 2 кн. : Особистісно орієнтований підхід : Теоретико-технологічні засади : навч.-метод. видання. Кн. 1. Київ. : Либідь, 280.

Асмолов, А. (2001). Психология личности: Принципы общепсихологического анализа. Москва: Смысл, 2001. 416 с.

Леонтьев, А. (1972). Проблемы развития психики. Москва: Просвещение, $436 \mathrm{c}$.

Леонтьев, А. (1977). Деятельность, сознание, личность. Москва: Просвещение, 289 с.

Бех, І. (2008). Виховання особистості : підручник для вищих навчальних закладів. Київ : Либідь, 840 с.

Пустовіт, Г. (2016). Педагогічна складова дозвіллєвої діяльності дитини у позашкільних навчальних закладах: сочіокультурні виклики. Інноватика у вихованні : зб. наук. пр. Вип.3 Рівне : РДГУ, С. 15-27.

\section{REFERENCES:}

Kremen, V. ta Ilin, V. (2012). Synerhetyka $v$ osviti: kontekst liudynotsentryzmu : monohrafiia [Synergetics in Education: the Context of Human-centrism: monograph.]. Kyiv: Pedahohichna dumka, 368 s.[in Ukrainian] 
Verkhovna rada Ukrainy, (2001). Natsionalna doktryna rozvytku osvity v Ukraini u XXI stolitti [National Doctrine for the Development of Education in Ukraine in the 21st Century. Kyiv: Shkilnyi svit, 24 s. [in Ukrainian]

Pustovit, H. (2014). Kompetentnisnyi pidkhid u zmistovykh konstruktakh osvity i vykhovannia osobystosti v pozashkilnykh navchalnykh zakladakh: teoretychni kontsepty [Competency Approach in the Content Constructs of Education and Personality Upbringing in Extracurricular Educational Institutions: Theoretical Concepts]. Naukovyi visnyk Chernivetskoho universytetu. Zbirnyk naukovykh prats Vypusk 689. Pedahohika i psykholohiia. Vyp.718. s. 152-163. [in Ukrainian]

Pustovit, H. (2011). Pozashkilni navchalni zaklady - pohliad u maibutnie [Out-ofschool Educational Institutions - a Look into the Future]. Nova pedahohichna dumka: materialy Vseukrainskoi naukovo-praktychnoi konferentsii [Formuvannia sotsialnoi kompetentnosti vykhovantsiv pozashkilnykh navchalnykh zakladiv]. Rivne. No 3. s. 17-19. [in Ukrainian]

Verkhovna rada Ukrainy, (2014). Zakon Ukrainy "Pro vyshchu osvitu” [Law of Ukraine "On Higher Education"]. Rezhym dostupu : URL: http://zakon2.rada.gov.ua/laws/show/1556-18/page. [Data zvernennia 3 bereznia 2019]. [in Ukrainian]

Vishnikina, L. (2017). Struktura predmetnoi heohrafichnoi kompetentnosti uchniv (rekomendatsii dlia vchyteliv heohrafii) [The Structure of the Subject Geographical Competence of Students (recommendations for geography teachers)]. Ukrainska profesiina osvita : naukovyi zhurnal Poltava. Vyp. 1. s.103-112. [in Ukrainian]

Pobydailo, N. (2017). Formuvannia kraieznavchoi kompetentnosti na zaniattiakh iz fizychnoi heohrafii ukrainy [Formation of Local Lore Competences at Physical Geography Lessons of Ukraine]. Profesionalizm pedahoha: teoretychni y metodychni aspekty. No $\quad 6 . \quad$ Rezhym dostupu: http://pptma.dn.ua/files/2017/6/18.\%20Pobidailo\%20159-168.pdf. [Data zvernennia 4 bereznia 2019]. [in Ukrainian]

Lokshyna, O. (2007). Rozvytok kompetentnisnoho pidkhodu v osviti Yevropeiskoho Soiuzu [Development of a Competent Approach in the Education of the European Union]. Shliakh osvity. No 4. S. 16-21. [in Ukrainian]

Bekh, I. (2006). Vykhovannia osobystosti: Skhodzhennia do dukhovnosti [Raising a Personality: Steps to Spirituality]: Naukove vydannia. Kn. 3. Kyiv: Lybid. 272 s. [in Ukrainian]

Bondar, V. (2008). Navchalna diialnist. Entsyklopediia osvity [Educational Activity. Encyclopedia of Education]. Kyiv: Khrinkom Inter, 1040 s. [in Ukrainian]

Bekh, I. (2003). Vykhovannia osobystosti : u 2 kn. : Osobystisno oriientovanyi pidkhid : Teoretyko-tekhnolohichni zasady : navch.-metod. vydannia [Education of a Person: in 2 books. : Personally Oriented Approach: Theoretical and Technological Principles: teaching method. edition]. Kn. 1. Kyiv. : Lybid, 280 s. [in Ukrainian]

Asmolov, A. (2001). Psikhologiya lichnosti: Pryntsypy obshchepsikhologicheskogo analiza [Personality Psychology: Principles of General Psychological Analysis]. Moskva: Smysl, 2001. 416 s.[in Russian]

Leontjev, A. (1972). Problemy razvitiya psikhiki [Problems of Development of the Psyche. Moskva: Prosveshcheniye, 436 s. [in Russian]

Leontjev, A. (1977). Deyatel'nost', soznaniye, lichnost' [Activity, Consciousness, Personality]. Moskva: Prosveshcheniye, 289 s. [in Russian]

Bekh, I. (2008). Vykhovannia osobystosti : pidruchnyk dlia vyshchykh navchalnykh zakladiv [Personality Upbringing: a textbook for higher education institutions]. Kyiv : Lybid, 840 s. [in Ukrainian]

Pustovit, H. (2016). Pedahohichna skladova dozvillievoi diialnosti dytyny u pozashkilnykh navchalnykh zakladakh: sotsiokulturni vyklyky [Pedagogical Component 
of Leisure Activity of a Child in Extracurricular Educational Institutions: Socio-cultural Challenges]. Innovatyka u vykhovanni : zb. nauk. pr. Vyp.3 Rivne : RDHU, s. 15-27. [in Ukrainian]

\title{
LOCAL LORE COMPETENCE OF THE GEOGRAPHY TEACHER IN INNOVATIVE DEVELOPMENT OF SCHOOL EDUCATION
}

\author{
Hryhorii Pustovit \\ Doctor in Pedagogy, Professor, \\ Professor at the Department of Natural and Mathematical Education \\ Rivne Region Institute of Postgraduate Pedagogical Education, \\ Rivne, Ukraine \\ ORCID: 0000-0001-7754-0249, \\ e-mail: h.pustovit@gmail.com
}

Ivan Zyl

Associate Professor at the Department of Ecology, Geography and Tourism Rivne State University of the Humanities

Rivne, Ukraine

ORCID: 0000-0002-1380-0432

e-mail: ivan_zil@ukr.net

\begin{abstract}
In the article it is outlined and characterized the essential features of the formation of local lore competence of Geography teachers in the innovative development of school education, and, the most important, the possibility of formation of the investigated phenomenon and its influence on the development and self-development of the teacher.

It has been clarified that the implementation of a competent approach to the preparation of Geography teachers is conditioned by the need to develop a systemic vision of the content of geographic education, prediction of a productive component of education, which requires adequate changes in the teacher training system.

It is actualized that the local lore competence of the Geography teacher involves mastering profound knowledge of a particular field of professional activity ((in our case, the organization and implementation of regional studies of school and students youth), and formed a stable motivational-emotional setting to achieve a high result of their own professional activities, the development of abilities, personal qualities, creative attitude to the teaching of a growing personality.

Therefore, local lore competence of the Geography teachers is defined and grounded as a multi-factor personal quality, in the structure of which the following competencies are established: motivational, emotional value, active-cognitive, subjectprofessional, self-development and research competency. The signs of independence of the Geography teacher in the development of their professional knowledge, abilities and skills on the organization and implementation of local lore work of children and student youth in school are described and characterized. Taking into account the essence and specificity of the organization and implementation by the geography teacher of the educational-cognitive, search-experimental and research local lore activities and the specific socially useful, massive or nature-protective work of students, the levels of its implementation is determined.
\end{abstract}

Key words: local lore competence, competencies, Geography teacher, innovative development of education, local lore activity, student, educational process, selfdevelopment.

Стаття надійшла до редакиії 07.05.2019 p. 